\title{
ANALISIS KESALAHAN BERBAHASA DALAM KARANGAN NARASI PADA SISWA KELAS V SDN MARGACINTA KECAMATAN SUMEDANG SELATAN
}

\author{
Anggi Citra Apriliana \\ STKIP Sebelas April Sumedang \\ Email: anggi.citra.apriliana@gmail.com
}

Naskah diterima : 13 Februari 2019, direvisi : 1 April 2019, disetujui : 15 April 2019

\begin{abstract}
This study aims to describe language errors (phonological, morphological, syntactic, semantic, and spelling errors) in narrative essays in class $V$ students of SDN Margacinta, South Sumedang District. To achieve these objectives a descriptive qualitative study was carried out with steps: collecting student language error data and analyzing language errors. The research subjects were fifth grade students of Margacinta Elementary School in South Sumedang District, Sumedang Regency. The results of the study showed that there were language errors in students' narrative essays which included errors in the fields of phonology, morphology, syntax, semantics, and spelling. Phonological errors were 23 (26.74\%), morphological errors were 7 (8.13\%), syntactic errors were 16 $(18.60 \%)$, semantic errors were $13(15.11 \%)$, and spelling errors were 27 (31.39\%). The most common error in the narrative essay is that the spelling error was 27 (31.39\%) while the least common type of error was errors in the morphology field of 7 (8.13\%) errors. Spelling mistakes that often appear are errors in capital letters, mistakes in writing prepositions, errors in the use of punctuation, and errors in writing words that are not in accordance with the rules of the correct language.
\end{abstract}

Keywords: Language Errors, Narrative Essays.

Pengutipan: Anggi Citra Apriliana. (2019). Analisis Kesalaban Berbahasa dalam Karangan Narasi pada Siswa Kelas V SDN Margacinta Kecamatan Sumedang Selatan. JMIE: Journal of Madrasah Ibtidaiyah Education,3(1), 2019, 11-21. jmie.v3i1.89.

Permalink/DOI: http://dx.doi.org/ 10.32934/jmie.v3i1.89 
Anggi Citra Aprilian

\section{PENDAHULUAN}

Tujuan pembelajaran bahasa Indonesia yang dijelaskan pada Kurikulum Tingkat Satuan Pendidikan (Depdiknas, 2006:124) bahwa, "Pembelajaran bahasa Indonesia diarahkan untuk meningkatkan kemampuan siswa dalam berkomunikasi dalam bahasa Indonesia dengan baik dan benar, baik secara lisan maupun tulis, serta menumbuhkan apresiasi terhadap hasil karya kesastraan manusia Indonesia". Proses belajar mengajar di sekolah menuntut adanya keteraturan penggunaan bahasa Indonesia yang baik dan benar. Alwi (2010: 21) menyatakan bahwa, "Bahasa yang baik adalah pemanfaatan ragam bahasa yang tepat dan serasi menurut golongan penutur dan jenis pemakaian bahasa. Sedangkan bahasa yang benar adalah pemakaian bahasa yang mengikuti kaidah yang dibakukan atau yang dianggap baku”. Dapat disimpulkan bahwa bahasa Indonesia yang baik dan benar yaitu bahasa Indonesia yang digunakan sesuai dengan norma kemasyarakatan dan sesuai dengan kaidah atau aturan bahasa Indonesia yang berlaku. Akan tetapi, pada kenyataan di lapangan siswa masih belum sepenuhnya menggunakan bahasa Indonesia yang baik dan benar. Untuk mengatasi hal tersebut perlu dilakukan sebuah analisis kesalahan berbahasa. "Kesalahan berbahasa secara sederhana dimaknai sebagai penggunaan bahasa, baik dilakukan secara lisan maupun tertulis yang menyimpang dari kaidah berbahasa"(Johan\&Simatupang, 2017: 242).

Kesalahan berbahasa adalah pemakaian bentuk-bentuk tuturan berbagai unit kebahasaan yang meliputi kata, kalimat, paragraf yang menyimpang dari sistem kaidah bahasa Indonesia baku, serta pemakaian ejaan dan tanda baca yang menyimpang dari sistem ejaan dan tanda baca yang telah ditetapkan dalam buku Ejaan Bahasa Indonesia yang disempurnakan. Sedangkan analisis kesalahan berbahasa adalah suatu cara atau langkah kerja yang biasa digunakan oleh peneliti atau guru bahasa untuk mengumpulkan data, mengidentifikasi kesalahan, menjelaskan kesalahan, mengklasifikasikan kesalahan dan mengevaluasi taraf keseriusan kesalahan berbahasa.

Kesalahan berbahasa biasanya ditentukan berdasarkan ukuran keberterimaan. Apakah bahasa (ujaran atau tulisan) si pembelajar bahasa itu berterima atau tidak bagi penutur asli atau pengajarnya. Jadi, jika pembelajar bahasa Indonesia membuat kesalahan, maka ukuran yang digunakan adalah apakah kata atau kalimat yang digunakan benar atau salah menurut penutur asli bahasa Indonesia. Jika kata atau kalimat yang digunakan pembelajar bahasa tadi salah, dikatakan bahwa pembelajar bahasa membuat kesalahan.

Dalam kehidupan sehari-hari, kita mengenal istilah kesalahan dan kekeliruan. Istilah kesalahan (error) dan kekeliruan (mistake), dalam pengakaran bahasa dibedakan yakni penyimpangan dalam pemakaian bahasa. Parera (Johan\&Simatupang, 2017: 242) mengungkapkan secara umum bahwa, "Kesalahan berbahasa dibedakan menjadi dua yaitu kesalahan berbahasa (error) dengan kekeliruan (mistake)". Kesalahan berbahasa (error) terjadi secara sistematis karena belum dikuasainya kaidah bahasa yang benar, sedangkan kekeliruan (mistake) disebabkan gagalnya merealisasikan kaidah bahasa yang sebenarnya sudah dikuasai. 
Menurut tarigan (2011: 75) bahwa, Kesalahan disebabkan oleh faktor kompetensi, artinya siswa belum memahami sistem linguistik bahasa yang digunakan. Kesalahan biasanya terjadi secara konsisten dan sistematis. Sebaliknya, kekeliruan pada umumnya disebabkan oleh faktor performansi. Kekeliruan itu bersifat acak, artinya dapat terjadi pada setiap tataran linguistic.

Berdasarkan pendapat di atas, dapat disimpulkan bahwa baik kesalahan (error) atau kekeliruan (mistake) keduanya memang sama-sama pemakaian bentuk tuturan yang menyimpang, akan tetapi kesalahan berbahasa terjadi secara sistematis karena belum dikuasainya kaidah bahasa yang benar. Sedangkan kekeliruan berbahasa bukan terjadi secara sistematis, melainkan dikarenakan gagalnya merealisasikan kaidah bahasa yang sebenarnya sudah dikuasai. Kesalahan berbahasa akan sering terjadi apabila pemahaman siswa tentang sistem bahasa kurang. Kesalahan berbahasa dapat berlangsung lama apabila tidak diperbaiki.

Analisis kesalahan berbahasa berdampak positif terhadap pembelajaran bahasa. Bahasa sebagai perangkat kebiasaan dipakai setiap orang sebagai media komunikasi yang sangat kompleks. Pada umumnya pemakai bahasa dalam berbahasa cenderung menggunakan jalan pikirannya tanpa mempertimbangkan aturan yang ada dalam bahasa.Analisis kesalahan berbahasa adalah suatu proses kerja yang digunakan oleh para peneliti bahasa dengan langkahlangkah pengumpulan data, penjelasan kesalahan tersebut, pengklasifikasian kesalahan tersebut berdasarkan penyebabnya, serta pengevaluasian taraf keseriusan kesalahan itu.

Berdasarkan pengamatan di lapangan, kesalahan berbahasa sering dialami siswa dalam menulis karangan narasi. Kesalahan berbahasa tersebut dapat disebabkan kekurangpahaman siswa mengenai ejaan yang baik dan benar. Selain itu, siswa mengalami kesulian dalam menulis karangan, kurang merespon dengan baik, kelihatan tidak senang dan kurang aktif. Hal ini tercermin pada siswa yang merasa bingung untuk mengeluarkan ide pikirannya, sehingga hasil karangan hanya terdiri dari dua atau tiga kalimat saja. Padahal, menulis karangan narasi merupakan salah satu bagian dari keterampilan menulis yang harus dikuasai oleh siswa kelas V. Keraf (2010:136) membatasi pengertian narasi sebagai "Suatu bentuk wacana yang sasaran utamanya adalah tindak tanduk yang dijalin serta dirangkaikan menjadi sebuah peristiwa yang terjadi dalam satu kesatuan waktu".

Beradasarkan permasalahan di atas, peneliti harus mencari solusi untuk mengatasi hal tersebut. Salah satu cara yang dapat digunakan untuk mengurangi dan mengatasi kesalahan tersebut adalah dengan mengadakan analisis kesalahan berbahasa siswa dalam menulis karangan sehingga peneliti dapat mengidentifikasi jenis kesalahan yang dilakukan siswa sehingga dapat menjadikan bahan refleksi untuk mengevaluasi kesalahan tersebut. Dari latar belakang di atas dapat penulis rumuskan masalah sebagai berikut.

1. Adakah kesalahan berbahasa dalam menulis karangan narasi pada siswa kelas V SDN Margacinta Kecamatan Sumedang Selatan Kabupaten Sumedang?

2. Seberapabesarkah kesalahan berbahasa dalam menulis karangan narasi pada siswa kelas $\mathrm{V}$ SDN Margacinta Kecamatan Sumedang Selatan Kabupaten Sumedang? 
Anggi Citra Aprilian

3. Jenis kesalahan berbahasa apakah yang paling banyak muncul dalam karangan narasi pada siswa kelas V SDN Margacinta Kecamatan Sumedang Selatan Kabupaten Sumedang?

Hasil Penelitian diharapkan dapat memberikan fakta-fakta aktual tentang:

1. Kesalahan berbahasa dalam menulis karangan narasi pada siswa kelas V SDN Margacinta Kecamatan Sumedang Selatan Kabupaten Sumedang.

2. Persentase kesalahan berbahasa yang muncul dalam karangan narasi pada siswa kelas $\mathrm{V}$ SDN Margacinta Kecamatan Sumedang Selatan Kabupaten Sumedang?

3. Kesalahan berbahasa yang paling banyak muncul dalam karangan narasi pada siswa kelas V SDN Margacinta Kecamatan Sumedang Selatan Kabupaten Sumedang.

\section{METODE PENELITIAN}

Berdasarkan tujuan yang akan dicapai dalam penelitian ini, peneliti menggunakan metode deskriptif kualitatif. Adapun yang dimaksud metode deskriptif adalah "Metode yang berusaha mendeskripsikan fakta apa adanya" (Arikunto, 2002:29). Dengan kata lain, penggunaan metode tersebut dimaksudkan untuk mendeskripsikan fakta-fakta tentang kesalahan berbahasa dalam karangan siswa kelas V di SDN Margacinta Kecamatan Sumedang Selatan, Kabupaten Sumedang.

Subjek penelitian ini yaitu siswa kelas V SDN Margacinta Kecamatan Sumedang Selatan Kabupaten Sumedang. Jumlah siswa yang dijadikan subjek penelitian sebanyak 20 siswa. Menurut Sutopo (Sugina, 2018: 63) jenis-jenis sumber data dalam penelitian kualitatif adalah kata-kata dan tindakan. Sumber data dalam penelitian ini berupa kata, tulisan, dan kalimat dalam karangan narasi siswa Kelas V. Alasan dipilihnya karangan narasi sebagai sumber data penelitian karena pada saat anak berada dalam masa middle and late childhood atau sekitar usia 6-11 tahun adalah saat mereka menguasai kemampuan dasar dalam membaca, menulis, menghitung (Santrock dalam Silitonga, 2016: 35). Kompetensi menulis yang diharapkan dari siswa SD yaitu dapat menulis karangan naratif dan nonnaratif dengan tulisan rapi dan jelas dengan memperhatikan tujuan dan ragam pembaca serta memakai ejaan, tanda baca, dan kosakata yang tepat. Instrumen penelitian adalah alat yang digunakan untuk mengumpulkan data atau mendapatkan data. Instrumen penelitian ini adalah peneliti itu sendiri (Human Instrumen). Peneliti sebagai instrumen kunci penelitian ini dituntut untuk memiliki kemampuan dan pengetahuan yang memadai tentang hal-hal yang berkaitan dengan masalah penelitian. Pemerolehan data dilakukan dengan mendatangi informan secara langsung. Untuk memperoleh data karangan narasi dari informan, peneliti membagikan selembar kertas yang berisi instruksi untuk menunjang penelitian dan mempermudah informan sebelum mereka menulis karangan narasi.

Teknik pengumpulan data yang digunakan yaitu teknik tes, teknik simak, dan teknik catat. Teknik tes digunakan dengan memberikan tes tertulis kepada siswa berupa tes mengarang. Materi tes dibatasi pada karangan narasi dengan standar kompetensi menulis yang menuntut penggunaan bahasa Indonesia yang baik dan benar. Menurut Mahsun (2005:90), “Teknik simak 
adalah suatu metode yang dilakukan untuk memperoleh data dengan menyimak penggunaan bahasa berupa wacana hasil tulisan siswa". Adapaun data yang dianalis berupa kesalahan berbahasa yang terdapat pada karangan narasi siswa yang meliputi kelalahan fonologi, morfologi, sintaksis, semantik, dan ejaan. Teknik catat digunakan untuk mencatat hasil simakan berupa kesalahan berbahasa siswa yang sudah terindetifikasi.

\section{HASIL DAN PEMBAHASAN}

Setelah data karangan narasi siswa kelas V sekolah dasar terkumpul, selanjutnya data tersebut dianalisis mengenai kesalahan berbahasa meliputi fonologi, morfologi, semantik, sintaksis, dan ejaan. Berdasarkan hasil analisis tersebut, diperoleh data sebagai berikut.

Tabel 2. Rekapitulasi Kesalahan Berbahasa dalam Karangan Narasi pada Siswa Kelas V SDN Margacinta Kecamatan Sumedang Selatan Kabupaten Sumedang

\begin{tabular}{|c|c|c|c|c|c|c|}
\hline \multirow[b]{2}{*}{ No. } & \multirow[b]{2}{*}{ No } & \multicolumn{5}{|c|}{ Jenis Kesalahan } \\
\hline & & Fonologi & Morfologi & Semantik & Sintaksis & Ejaan \\
\hline 1. & S01 & 1 & 1 & 1 & 1 & 1 \\
\hline 2. & $\mathrm{~S} 02$ & & & 2 & & 1 \\
\hline 3. & S03 & 1 & & & 1 & 2 \\
\hline 4. & S04 & 2 & & & 1 & 1 \\
\hline 5. & S05 & & 1 & & & 1 \\
\hline 6. & S06 & 1 & & & 1 & 3 \\
\hline 7. & S07 & 4 & 1 & 2 & & 1 \\
\hline 8. & S08 & 6 & 4 & & & 1 \\
\hline 9. & S09 & & & 1 & 1 & 4 \\
\hline 10. & $\mathrm{~S} 10$ & & & & 3 & \\
\hline 11. & S11 & 1 & & 1 & & \\
\hline 12. & $\mathrm{~S} 12$ & & & & & 3 \\
\hline 13. & S13 & 2 & & 1 & 2 & 2 \\
\hline 14. & S14 & & & 1 & 1 & \\
\hline 15. & S15 & 2 & & & & \\
\hline 16. & $\mathrm{~S} 16$ & 1 & & 1 & 1 & 1 \\
\hline 17. & S17 & 2 & & & 1 & 2 \\
\hline 18. & S18 & & & & 2 & 1 \\
\hline 19. & S19 & & & 1 & 1 & 1 \\
\hline 20. & S20 & & & 2 & & 2 \\
\hline & & 23 & 7 & 13 & 16 & 27 \\
\hline & tase & $26,74 \%$ & $8,13 \%$ & $15,11 \%$ & $18,60 \%$ & $31,39 \%$ \\
\hline & ori & HS & SK & SK & SK & HS \\
\hline
\end{tabular}


Anggi Citra Aprilian

Berdasarkan tabel di atas, diperoleh data kesalahan berbahasa pada karangan narasi siswa kelas V SDN Margacinta yaitu, kesalahan fonologi sebesar 23 (26,74\%), kesalahan morfologi sebesar 7 (8,13\%), kesalahan semantik sebesar 13 (15,11\%), kesalahan sintaksis sebesar 16 (18,60\%), dan kesalahan ejaan sebesar 27 (31,39\%). Kesalahan yang paling banyak muncul pada karangan narasi siswa tersebut yaitu, kesalahan dalam bidang ejaan sebesar 27 $(31.39 \%)$.

\section{Rekapitulasi Kesalahan Berbahasa SDN Margacinta}

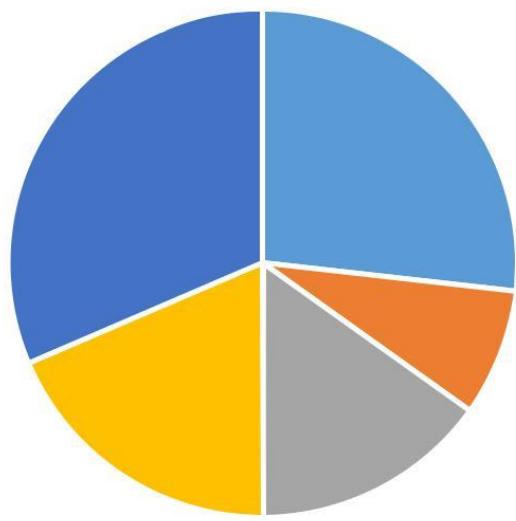

Fonologi Morfologi Semantik Sintaksis Ejaan

\section{Diagram 1. Rekapitulasi Kesalahan Berbahasa SDN Margacinta}

Berdasarkan hasil penelelitian tersebut, di bawah ini akan dipaparkan bagaimana kesalahan fonologi, morfologi, semantik, sintaksis, dan ejaan pada karangan narasi siswa SDN Margacinta.

\section{Kesalahan dalam Fonologi}

Kesalahan fonologi dalam karangan narasi siswa Kelas V SDN Margacinta disebabkan oleh penambahan fonem, pengurangan fonem, dan kesalahan pemenggalan suku kata.

a. Penambahan Fonem

S17: Pepohonan itu berjejer di mana sajah. Pada kalimat tersebut terdapat penambahan fonem $h$ di akhir kata saja. Seharusnya Pepohonan itu berjejer di mana saja.

b. Pengurangan Fonem

S04: Lapangan dan halaman sekolah kotor karna banyak sampah berserakan. Pada kalimat tersebut terdapat pengurangan fonem $e$ pada kata karna. Seharusnya Lapangan dan halaman sekolah kotor karena banyak sampah berserakan. 
S07: Aku meliat rumah-rumahan. Pada kalimat tersebut terdapat pengurangan fonem h pada kata meliat. Seharusnya Aku melihat rumah-rumahan.

S07: Aku pergi ke rumah kake dan nene. Pada kalimat tersebut terdapat pengurangan fonem $\mathbf{k}$ pada kata kake dan nene. Seharusnya, Aku pergi ke rumah kakek dan nenek.

c. Kesalahan pemenggalan suku kata

S03: Pepohonan yang sangat indah dan pegunu-ngan yang sejuk. Seharusnya, Pepohonan yang sangat indah dan pegunung-an yang sejuk.

\section{Kesalahan dalam Morfologi}

Kesalahan morfologi dalam karangan narasi siswa Kelas V SDN Margacinta disebabkan oleh penulisan morfem yang salah dan perulangan yang salah.

a. Penulisan morfem yang salah

S01: Aku menghirup udara pagi yang sangang sejuk dan indah. Seharusnya,

Aku menghirup udara pagi yang sangat sejuk dan indah.

b. Perulangan yang salah

S07: Aku berenang bersama teman2. Seharusnya, Aku berenang bersama teman-teman.

\section{Kesalahan dalam Sintaksis}

Kesalahan dalam bidang sintaksis meliputi kesalahan dalam bidang frasa, klausa, dan kalimat. Kesalahan sintaksis dalam karangan narasi siswa kelas V SDN Margacinta disebabkan oleh kalimat tidak efektif. Suatu kalimat dikatakan efektif apabila mampu mencapai sasaran dengan baik sebagai alat komunikasi. Ada beberapa faktor yang menyebabkan suatu kalimat dikatakan tidak efektif apabila kalimat tidak logis, kalimat rancu, penggunaan subjek yang berlebihan, pengaruh struktur bahasa daerah, ambigu, ketidakefektifan bentuk kata, dan kemubaziran kata. Kesalahan sintaksis dalam karangan narasi siswa kelas V SDN Margacinta sebagai berikut.

a. Kalimat Rancu

Kalimat rancu merupakan kalimat yang susunannya tidka teratur sehingga sulit dipahami.

S03: Indahnya lagi di jalan tidak ada satupun dedaunan yang berserakan di jalan. Seharusnya, Jalan itu sangat indah karena tidak ada dedaunan yang berserakan.

S10: Aku bersekolah di sebuah sekolah. Seharusnya, Aku sekolah di SDN Margacinta. 
Anggi Citra Aprilian

b. Ketidakjelasan Subjek

S06: Pada suatu hari pergi ke kebun mencari burung. Seharusnya, Pada suatu hari ayah pergi ke kebun mencari burung.

c. Kalimat Tidak Logis

S14: Di rumahku aku menanam bunga. Seharusnya, Aku menanam bunga di halaman rumah.

S19: Aku melanjutkan lagi perjalanan ke sekolah bersama ayah memakai sepeda motor. Seharusnya, Aku dan ayah melajutkan perjalanan ke sekolah dengan mengendarai sepeda motor.

d. Pengaruh Bahasa Daerah

S17: Pepohonan itu berjejer di mana saja. Seharusnya, Pepohonan itu berjajar di mana saja.

\section{Kesalahan dalam Semantik}

Semantik merupakan bagian tata bahasa yang meneliti makna dalam bahasa tertentu. Kesalahan bahasa dalam bidan semantik di antaranya yaitu gejala hiperkorek dan pleonasme. Hiperkorek adalah suatu bentuk yang sudah benar lalu dibenar-benarkan sehingga akhirnya menjadi salah. Misalnya /sy/ diganti menjadi /s/ atau sebaliknya. Syarat dijadikan sarat atau sebaliknya, padahal ke dua kata tersebut memiliki arti berbeda. Syarat memiliki arti 'ketentuan/aturan' sedangkan sarat memiliki arti 'penuh'. Contoh dalam kalimat:

- Kita harus mengikuti syarat itu.

- Mobil itu sarat muatan.

Sedangkan pleonasme adalah penggunaan unsur-unsur bahasa secara berlebihan. Misalnya, Bajumu sangat indah sekali. Seharusnya, Bajumu sangat indah atau Bajumu indah sekali.

Kesalahan semantik dalam karangan narasi kelas V SDN Margacinta sebagai berikut.

a. Pleonasme

S02: Saya dan teman-teman berkumpul di lapangan saya membekal makanan yang sangat banyak. Seharusnya, Saya dan teman-teman berkumpul di lapangan dengan membawa bekal makanan yang banyak.

S11: Di pagi hari aku melihat sekolah SDN Margacinta sangat bersih. Seharusnya, Di pagi hari aku melihat SDN Margacinta sangat bersih.

S19: Aku tidak menyerah dan aku terus mencoba lagi. Seharusnya, Aku tidak menyerah dan terus mencoba lagi. 
S20: Saya di bantu oleh teman saya dan saya ganti baju. Seharusnya, Saya dibantu teman untuk ganti baju.

\section{Kesalahan dalam Ejaan}

\section{a. Kesalahan Pemakaian Huruf Kapital}

Kesalahan ejaan dalam karangan disebabkan oleh kesalahan penggunaan huruf, salah satunya kesalahan penggunaan huruf kapital. Kesalahan pemakaian huruf kapital mencakup kesalahan huruf dalam penulisan nama geografi, kesalahan huruf dalam penulisan judul karangan, kesalahan huruf dalam penulisan nama hari, kesalahan huruf dalam penulisan awal kalimat, kesalahan huruf dalam penulisan nama orang.Kesalahan pemakaian huruf kapital dalam karangan narasi siswa kelas V SDN Margacinta sebagai berikut.

S08: Pada hari minggu Aku Pergi ke Kebun bersama nenek dan kakek. Seharusnya, Pada hari Minggu aku pergi ke kebun bersama nenek dan kakek.

\section{b. Kesalahan Penulisan Kata}

Kesalahan penulisan kata yang ditemukan adalah penulisna partikel, preposisi, penulisan angka dan lambang bilangan. Pada penulisn partikel, siswa banyak menulis partikel -pun dirangkai dengan kata sebelumnya. Kebiasaan menggunakan partikels-pun yang dirangkai karena kurangnya pemahaman siswa terhadap penggunaan partikel. Kesalahan tersebut akan terulang jika guru tidak memberikan penjelasan tentang ketentuan penulisan yang benar kepada siswa.

Kesalahan penulisan kata dalam karangan narasi siswa kelas V SDN Margacinta sebagai berikut.

S12: Disekitar hutan saya dan teman-teman memetik buah jambu. Seharusnya, Di sekitar hutan, saya dan teman-teman memetik buah jambu. Kata depan di, ke, dan dari harus ditulis terpisah dari kata yang mengikutinya.

\section{c. Kesalahan Penggunaan Tanda Baca}

Kesalahan penggunaan tanda baca yang ditemukan dalam karangan siswa SD tidak sedikit jumlahnya. Banyak siswa yang belum dapat menggunakan tanda baca dengan benar. Kesalahan penggunaan tanda baca yang ditemukan mencakup kesalahan penggunaan tanda titik pada akhir kalimat, kesalahan penggunaan tanda koma, dan kesalahan penggunaan tanda hubung. Kesalahan penggunaan tanda baca titik dalam karangan narasi siswa kelas V SDN Margacinta sebagai berikut.

S01: di sepanjang jalan tidak ada satupun sampah yang berserakan.dan banyak pepohonan yang sangat indah. Seharusnya, Di sepanjang jalan tidak ada satupun sampah yang berserakan dan banyak pepohonan yang sangat indah. 
Anggi Citra Aprilian

\section{PEMBAHASAN}

Kesalahan dalam bentuk ejaan merupakan kesalahan yang sering muncul pada karangan narasi siswa kelas V SDN Margacinta. Hal ini harus mendapatkan perhatian khusus dari guru supaya dapat meminimalisir kesalahan tersebut. Seperti penelitian yang telah dilakukan oleh Susan Nauli Silitonga yang berjudul Analisis Kesalahan Ejaan dalam Karangan Siswa SD Negeri Gemawang Sinduadi Mlati Sleman pada tahun 2016, dapat disimpulkan bahwa jenis kesalahann yang sering muncul yaitu pada penulisan huruf kapital serta kesalahan dalam penggunaan tanda baca. Pada dasarnya siswa kurang memahami mengenai fungsi dan kegunaan huruf kapital. Fungsi huruf kapital sebagai berikut.

1. Huruf pertama kata pada awal kalimat.

2. Huruf kapital dipakai sebagai huruf pertama petikan langsung.

3. Huruf kapital dipakai sebagai huruf pertama dalam ungkapan.

yang berhubungan dengan nama Tuhan dan kitab suci, termasuk kata ganti untuk Tuhan,

4. Huruf kapital dipakai sebagai huruf pertama nama gelar kehormatan, keturunan, dan keagamaan yang diikuti nama orang,

5. Huruf kapital sebagai huruf pertama unsur nama jabatan dan pangkat yang diikuti nama orang atau yang dipakai sebagai pengganti nama orang tertentu, nama instansi, atau nama tempat.

6. Huruf kapital dipakai sebagai huruf pertama unsur-unsur nama orang.

7. Huruf kapital dipakai sebagai huruf pertama nama bangsa, suku bangsa, dan bahasa.

8. Huruf kapital dipakai sebagai huruf pertama nama tahun, bulan, hari, hari raya, dan peristiwa sejarah.

9. Huruf kapital dipakai sebagai huruf pertama nama geografi.

Selain itu, berdasarkan hasil penelitian yang telah dilakukan oleh Sugina tahun 2018 dengan judul penelitian Analisis Kesalahan Berbahasa Karangan Narasi Siswa Kelas V Sekolah Dasar Negeri 01 Karangpandan Kabupaten Karanganyar, kesalahan dalam ejaan menempati kesalahan yang terbesar dalam penelitian ini yaitu sejumlah 63 kesalahan. Berdasarkan temuan di atas, siswa harus mendapatkan bimbingan khusus terkait dengan bentuk kesalahan dalam bidang ejaan sehingga dapat meminimalisis bentuk kesalahan yang dialami siswa.

\section{SIMPULAN}

Berdasarkan hasil pengolahan data analisis kesalahan berbahasa pada karangan narasi siswa kelas V SDN Margacinta Kecamatan Sumedang Selatan Kabupaten Sumedang, maka peneliti menyimpulkan hal-hal sebagai berikut.

1. Terdapat kesalahan berbahasa dalam karangan narasi pada siswa kelas V SDN Margacinta

Kec. Sumedang Selatan Kabupaten Sumedang. Kesalahan berbahasa tersebut mencakup kesalahan fonologi, morfologi, sintaksis, semantik, dan ejaan. 
2. Persentase kesalahan berbahasa pada karangan narasi siswa kelas V SDN Margacinta yaitu, kesalahan fonologi sebesar 23 (26,74\%), kesalahan morfologi sebesar 7 (8,13\%), kesalahan sintaksis sebesar 16 (18,60\%), kesalahan semantik sebesar 13 (15,11\%), dan kesalahan ejaan sebesar 27 (31,39\%).

3. Kesalahan berbahasa yang sering banyak muncul yaitu kesalahan dalam bentuk ejaan sebesar 27 kesalahan (31,39\%), sedangkan jumlah kesalahan berbahasa terkecil yaitu dalam bidang morfologi sebesar 7 kesalahan (8,13\%). Kesalahan ejaan yang sering muncul yaitu kesalahan penulisan huruf kapital, kesalahan penulisan kata depan, kesalahan pemakaian tanda baca, kesalahan penulisan kata yang tidak sesuai dengan kaidah bahasa yang benar, dan kesalahan penulisan partikel.

\section{DAFTAR PUSTAKA}

Alwi, Hasan. (2010). Tata Bahasa Baku Bahasa Indonesia Edisi Ketiga.Jakarta: Balai Pustaka Arikunto, Suharsimi. (2002). Prosedur Penelitian Suatu Pendekatan Praktek. Jakarta: Rineka Cipta.

Depdiknas. (2006). Kamus Besar Bahasa Indonesia. Jakarta: Balai Pustaka.

Johan dan Simatupang. (2017). Analisis Kesalahan Berbahasa Indonesia Secara Sintaktis dalam Proses Diskusi Siswa Kelas IV SDN Miri. Jurnal Visipena Volume 8 Nomor 2. [Online]. Tersedia: http://www.visipena.stkipgetsempena.ac.id/home/article/download/185/174 [12 Agustus 2018].

Keraf, Gorys. (2010). Argumentasi dan Narasi. Jakarta: Gramedia.

Mahsun. (2005). Metode Penelitian Bahasa: Tahapan, Strategi, Metode, dan Tekniknya. Jakarta:Raja Grafindo Persada.

Silitonga, Susan Nauli. (2016). Analisis Kesalahan Ejaan Dalam Karangan Siswa Sd Negeri Gemawang Sinduadi Mlati Sleman.(Online). Tersedia: http://eprints.uny.ac.id/37769/1/Susan\%20Nauli\%20Silitonga\%2009210144028.pdf. (diakses 10Agustus 2018).

Sriyanto. (2015). Ejaan. Jakarta: Pusat Pembinaan Kementerian Pendidikan dan Kebudayaan.

Sugina. (2018). Analisis Kesalahan Berbahasa Karangan Narasi Siwa Kelas V Sekolah Dasar Negeri 01 Karangpandan Kabupaten Karanganyar. Jurnal Silistika Vol.4, No 12018: 59-70 (Online).Tersedia:http://journal.univetbantara.ac.id/index.php/stilistika/article/downl oad/98/88http://journal.univetbantara.ac.id/index.php/stilistika/article/download/98 $\angle 88$ (diakses 12 Agustus 2018).

Sugiyono. (2007). Metode Penelitian Pendidikan Pendekatan Kuantitatif, Kualitatif, dan R\&D. Bandung: Alfabeta.

Tarigan, Henry Guntur. (2011). Pengajaaran Analisis Kesalahan Berbahasa. Bandung:Angkasa. 